\title{
Healthcare Encounters End Date Time
}

National Cancer Institute

\section{Source}

National Cancer Institute. Healthcare Encounters End Date Time. NCI Thesaurus. Code C123956.

The date and time a healthcare encounter assessment has concluded. 